\title{
A COVID-19 JÁRVÁNY VÁRHATÓ HATÁSAI OLASZORSZÁG ÁLLAMADÓSSÁGÁNAK KÖZÉP- ÉS HOSSZÚ TÁVÚ FINANSZÍROZÁSÁRA
}

\author{
Török László
}

\begin{abstract}
Absztrakt: A koronavírus járvány társadalmi-gazdasági következményei napjainkban a közérdeklődést leginkább foglalkoztató téma. Természetesen a társadalom és a közgazdasági szakma közvéleményét a várható negatív gazdasági hatások érdeklik a leginkább. A következmények közül is kitüntetett figyelem irányul az államok bruttó adósságának növekedésére és azok pénzügyi finanszírozására. Olaszország ebben az összefüggésben kiemelkedik az Európai Unió tagországai közül. Az olaszok kitűntetett szerepének az a magyarázata, hogy abszolút összegben és adósság rátában is ennek az országnak az államadóssága fog a legnagyobb mértékben növekedni az Unió országai közül. A tanulmány egy ökonometriai modell alkalmazásával bemutatja az olasz államadósság várható növekedését. Ezt a növekedést négy járványlefutási forgatókönyv alapján számszerüsíti a tanulmány. A kutatás végkövetkeztetése az, hogy bármilyen módon fog a koronavírus járvány véget érni, Olaszország drasztikusan megemelkedő államadósságának finanszírozása hatalmas erőfeszítéseket fog igényelni. Ennek ellenére az sem zárható ki, hogy Olaszországnak néhány éven belül a rendezett államcsőd lehetőségével kell élni.
\end{abstract}

\begin{abstract}
The socio-economic consequences of the coronavirus epidemic are a topic of most public interest today. Of course, the public of the society and the economic profession is most interested in the expected negative economic effects. Among the consequences, special attention is paid to the growth of the gross debt of the states and their financial financing. In this context, Italy stands out among the Member States of the European Union. The privileged role of the Italians is explained by the fact that, both in absolute terms and in terms of debt, this country's public debt will increase the most among the countries of the Union. The study uses an econometric model to show the expected increase in Italian public debt. This increase is quantified by the study based on four epidemic scenarios. The research concludes that in whatever way the coronavirus epidemic will end, financing Italy's drastically rising public debt will require a huge effort. Nevertheless, it cannot be ruled out that Italy will have to resort to the possibility of an orderly state bankruptcy within a few years.
\end{abstract}

Kulcsszavak: COVID-19 járvány, államadósság, finanszírozás, Olaszország

Keywords: COVID-19 epidemic, public debt, financing, Italy

\section{Bevezetés}

Egy korábbi tanulmányomban az Európai Unió minden egyes tagországára nézve vizsgáltam meg a COVID-19 járvány várható hatását a bruttó államadósság-ráták alakulására (Török, 2020). A kutatási téma azonos teoretikus megközelítése miatt találhatók nem jelentős mértékü elméleti megalapozást szolgáló azonosságok jelen tanulmányban az abban foglaltakkal.

A szuverén bruttó konszolidált államadósság megfelel a múltban felhalmozott államháztartási hiány kumulált összegének. Ezzel párhuzamosan a múltban voltak és a jövőben lesznek olyan tételek, amelyek nem jelentek meg, illetve nem fognak megjelenni a hiányban (IMF, 2015). Amennyiben az államháztartás kiadásai egy adott évben meghaladják a bevételeit, akkor az így keletkezett hiány finanszírozására az állam adósságpapírokat (jellemzően kincstárjegyeket és államkötvényeket) bocsáthat ki, vagy hitelt vehet fel. A hiány finanszírozására kibocsátott 
adósságelemeknek az évek során felhalmozódott állománya az államadósság (Arena, 2010).

Az államnak a meglévő adóssága után kamatfizetési kötelezettsége áll fenn. Egy eladósodott országban az állam kamatfizetések nélkül számított úgynevezett elsődleges egyenlege hiába kerül egyensúlyba, önmagában a kamatfizetések miatt hiány alakul vagy alakulhat ki (Török, 2012). Egy nemzetgazdaság államadósságának alakulását az államháztartási hiány mellett a gazdasági növekedés és az ország inflációját meghaladó reálkamat befolyásolja még. Ezeknek a tényezőknek a meghatározó szerepét fogja a tanulmány bemutatni Olaszország várható államadósságára vonatkozóan.

\section{A bruttó államadósság különböző mértékei}

A közgazdaságtudományban nincs egzakt szabály arra vonatkozóan, hogy mekkora az optimális mértéke egy adott nemzetgazdaság adósságrátájának. A maastrichti szerződésben foglalt 60 százalékos numerikus arány egy konvencionális megállapodás terméke, egyfajta igazodási pont. Az államadósságnak erre a mértékére mindössze az az elöírás vonatkozik, hogy jó, ha „kielégítö ütemben” közelíti a GDP arányában meghatározott szintet (Benczes-Kutasi, 2016).

Számos tanulmány vizsgálta azt, hogy az államadósság milyen mértéke az, amely már negatívan hat egy adott nemzetgazdaság gazdasági növekedésére. Ezt vizsgálva (Reinhart-Rogoff, 2010), arra a következtetésre jutottak, hogy a GDP 90 százaléka feletti államadósság csökkenti az adott nemzetgazdaság növekedését. Ezzel szemben (Herndon et al., 2010) azt állapították meg, hogy nincs nagy különbség a 90 százalékos küszöbérték alatti vagy feletti adósságállománnyal rendelkező országok átlagos és medián GDP-növekedésében. Következtetésük az, hogy az államadósság és a GDP növekedése jelentősen különbözött országonként és időszakonként. Olaszország jelenlegi államadóssága jelentősen magasabb a 90 százalékos mértéknél, a koronavírus járvány miatt pedig drasztikusan meg fog növekedni a ráta értéke. Vannak olyan nemzetgazdaságok, ahol az államadósság meghaladja a 230 százalékot. Példa erre Japán, ahol az államadósság GDP-hez viszonyított aránya 237 százalék volt 2019-ben. A szakértők eltérő véleményen vannak erről a magas rátáról, számos tanulmány kimutatta, hogy a finanszírozás szempontjából ez már riasztóan magas államadósság-ráta (Tomomi-Kazuki, 2017).

Fontos felismerésekre jutottak a pénzügyi válság után az államadósságról végzett kutatások. Egyik ilyen felismerés volt globális államadósság növekedés kutatásának az, hogy a monetáris politika önmagában nem elegendö. A pénzügyi válságkezelés során szükség van a fiskális politika aktív használatára is (Blanchard et al., 2010). Hasonló megállapításra jutott Arestis (2014) kutatásában. Ebben ő kiemeli, hogy a nemzeti gazdaságpolitikák erősödnek, ha a monetáris és a fiskális politika megfelelően összehangolódik a pénzügyi stabilitás megteremtése érdekében. 


\section{Olaszország gazdasága a koronavírus járvány előtt}

Olaszország COVID-19 előtti társadalmi-gazdasági állapotának, a közeljövőben várható tendenciáinak rövid összefoglalását adja az Index (2020). Az olasz gazdaság rossz állapotát jelzi, hogy a 2019 évi bruttó hazai össztermék, az éves GDP alig több, mint a 2004 évben mért érték. Az olasz gazdaság növekedési üteme a 2008-as pénzügyi válság óta csak háromszor haladta meg az éves egy százalékot. Az olaszoknál már a koronavírus járvány előtt is alacsony volt a növekedés értéke. 2019 utolsó negyedévében 0,3 százalékkal csökkent a GDP az elöző félévhez képest, az év egészét tekintve csak 0,3 százalékkal nőtt. A gazdasági növekedésnek ez az értéke a legalacsonyabb volt az Európai Unióban. Az ipari termelés egy éve csökken, a munkanélküliség 10 százalék környékén van, a 25 éven aluliak körében ennél is nagyobb, 28,9 százalék, az államadósság a GDP 130-135 százaléka között stabilizálódott. Ez a ráta a második legmagasabb az Unióban.

Az olasz gazdaság termelékenysége évtizedek óta stagnál, a foglalkoztatási ráta a legalacsonyabb a fejlett országok között. Olaszország az elmúlt 15 évben gazdaságilag szinte nem fejlődött semmit. A gazdaság stagnálásának okai régi problémákra vezethetök vissza. Az olaszok arányaiban kevesebb pénzt invesztáltak az oktatásba és a technológiai innovációba, mint a németek, vagy a franciák. Emiatt az olasz munkaerő képzettsége gyenge, a gazdaság legnagyobb arányát jelentő kisés középvállalkozások versenyképessége rossz. Visszafogja az olasz gazdaságot a társadalom öregedése és a jelentős külföldi elvándorlás is. Közkeletủ adat az, hogy a jól képzett dolgozók ötöde külföldön vállal munkát. Közismert az is, hogy alacsony hatékonyságú az államigazgatás és körülményes az olasz jogi szabályozás.

Fontos tényező még az olasz bankszektor jelenlegi rossz állapota is. Az olasz bankoknak sok nem teljesítő hitel van, ami azt jelenti, hogy az adósok egy jelentős része nem fizeti vissza a bankoktól korábban felvett hitelét. A nem teljesítő hitelek aránya az összes hitelhez viszonyítva 2016-ban 18 százalékon tetőzött. Értéke meghaladta a 350 milliárd eurót, ebből 200 milliárd a teljesen bedőlt, soha vissza nem fizetett kölcsönök összege. Ez a probléma évek óta létezik, amely egy súlyosabb válság esetén magával ránthat sok más európai bankot. Ezt a banki problémát az utóbbi években sikerült a világgazdaságban tapasztalt pénzbőségnek és más intézkedések segítségével mérsékelni. Napjainkban már kevéssel jobb a hitelezési helyzet, mint néhány évvel ezelött volt.

Összefoglalva az kijelenthető, hogy az olasz gazdaság azért tudott egyáltalán müködni az utóbbi években, mert kedvező külső világgazdasági környezet volt a globális gazdaságban. Ennek része volt a fejlett világban megtapasztalt pénzügyibefektetési forrásböség és alacsony kamatkörnyezet, valamint az Európai Központi Bank (ECB) olaszokat támogató monetáris politikája is (Reuters, 2020).

\section{Olaszország szuverén bruttó államadóssága}

Az olasz államadósság 2019-ben mintegy 2300 milliárd euró, a bruttó hazai termékének több, mint 134 százaléka (Eurostat, 2020). Ez Görögország után a 
második legmagasabb arány az Európai Unióban, több mint duplája a maastrichti 60 százalékos uniós ajánlásnak.

Olaszország 2010-2019 közötti államadósságának változását mutatja az 1. ábra:

\section{1. ábra: Olaszország bruttó államadósságának alakulása a GDP százalékában (2010-2019)}

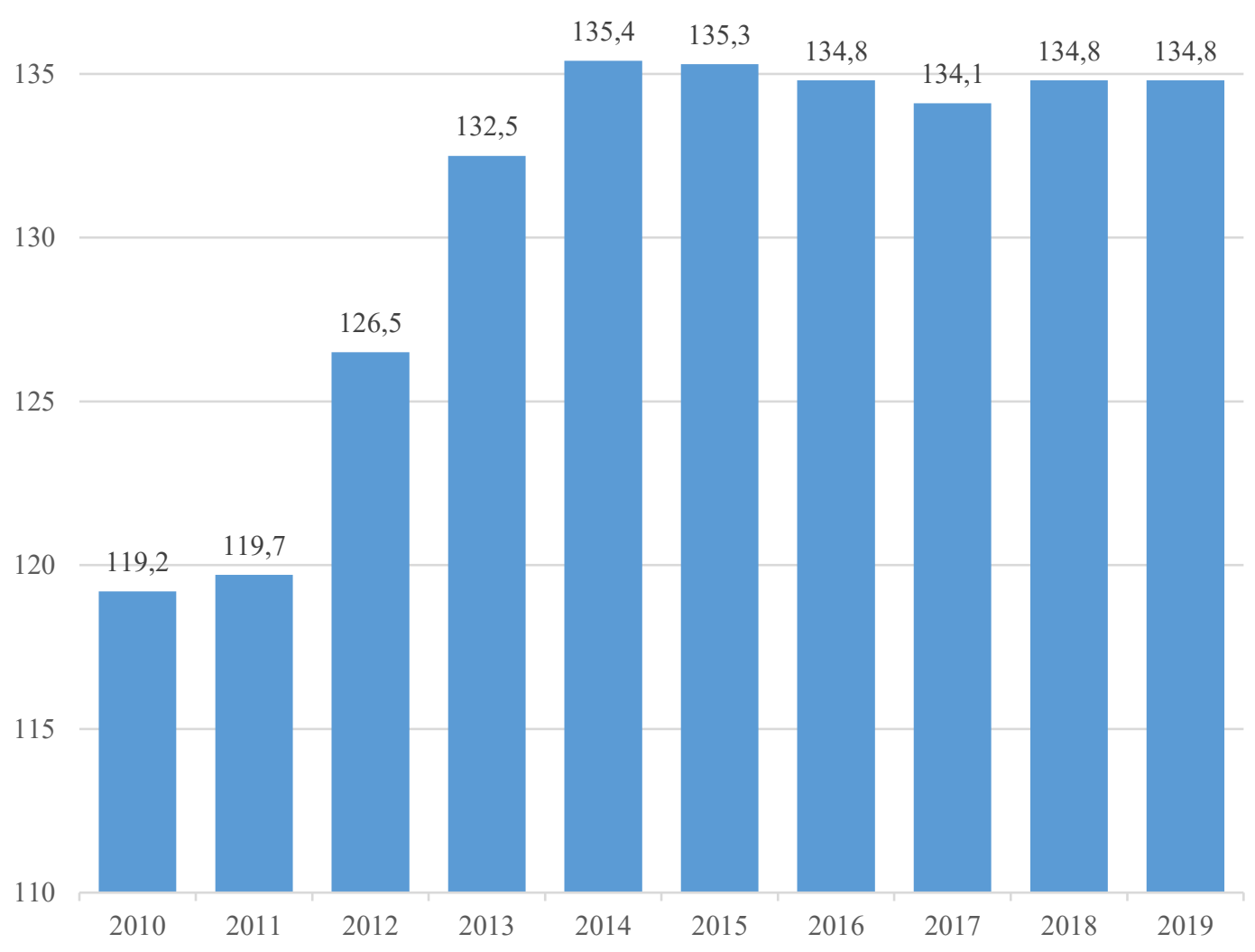

Forrás: Eurostat (2020) alapján, saját szerkesztés

Olaszország bruttó államadóssága 2008-ban még csak 106 százalék volt. A 2008-ban kialakult globális pénzügyi válság azonban az olasz állami költségvetést is nehéz helyzetbe hozta. A költségvetés hiánya eröteljesen növekedett, ennek következtében az államadósság is emelkedni kezdett. Az olasz államháztartás pénzügyi megszorító intézkedései és az elkezdődő globális növekedés meghozta az eredményeket. A költségvetési hiány tekintetében az eurózóna átlagához képest az olaszok kifejezetten jobb adatokat értek el. Szinte egyedülálló módon, már 2013-ra megvalósult az olaszoknál a költségvetési egyensúly, az államadósság csak kis mértékben növekedett (Czékus, 2012). Ezt követő években az államadósság rátája alig 3 százalékot emelkedett, ezután mérsékelten csökkeni kezdett, a múlt évben 134,8 százalékon zárt. A kismértékủ csökkenés azt jelezte, ha nem fog a gazdaságban 
recesszió bekövetkezni, akkor az olasz állam eladósodása csökkenő pályára fog állni. $\mathrm{Az}$ olasz vállalatok versenyképességi lemaradása a nemzetközi élmezőnytől is hozzájárul ahhoz, hogy a költségvetés (és annak hiányából következően is az államadósság) nehezen képes érdemben javulni. Az olasz vállalati versenyképesség mérséklődésének részletesebb elemzését adja Grimaldi (2019).

\section{Koronavírus járvány hatása Olaszország gazdaságára}

A koronavírus járvány az elsők között kezdett el terjedni Olaszországban, azon belül is annak Északi országrészében. Ez a terület Európa leggazdagabb és legdinamikusabb régiói között van, az olasz gazdaság harmadát teszik ki. Lombardia egyedül az ipari termelés és az export 40-40 százalékát adja. Az autógyárak és más ipari üzemek mellett a pénzügyi világ, a divat és a luxusmárkák központjai is itt vannak.

A járvány elsőként az olasz gazdaság egyik legfontosabb szektorát támadta meg, a GDP 14 százalékát adó turizmus ágazatot. A szállodáknak 50-80 százalék közötti foglalástörlésekre kell számítani. Hatalmas GDP csökkenést fog jelenteni az olaszoknak, ha a föszezonban elmaradnak a jelentös turisztikai bevételek. Olaszország gazdaságát három olyan tényező is nehezíti, amelyek az államadósság növekedését fogják okozni. Ezek közül az első tényező a gazdasági kibocsátás csökkenése. Ez a GDP visszaesésében fog megmutatkozni. Ennek mértékét pontosan nem lehet meghatározni, csak azt lehet biztosan tudni, hogy a GDP csökkenés 8,211,3 százalék között várható. A gazdaság több hónapos leállása miatt a termelö és szolgáltató ágazatok kibocsátása jelentősen csökkeni fog. A második tényező az olasz költségvetés várható deficitje. Ennek mértéke az előrejelzések szerint -8,3 és 10,3 százalék között lesz (RAM, 2020).

Az olasz állam sok támogatást fog adni a gazdaságnak azért, hogy az müködni tudjon. A háztartásokat is támogatásban kell részesíteni, például a megemelkedö munkanélküliség miatt. Erre azért lesz szükség, hogy ne alakuljon ki tömeges elszegényedés. A GDP visszaesése miatt gazdaság és a háztartások sokkal kevesebb adót és társadalombiztosítási járulékot fognak az államnak befizetni, ezért is csökkenni fog az államháztartás bevétele. Végül a harmadik tényező, ami Olaszország államadósságát befolyásolni fogja, az a reálkamatának jövőbeli mértéke. A reálkamat az a kamat többlet, amivel az államadósságot finanszírozó államkötvények után az infláció felett kell az államnak kifizetni a hitelezők javára. A reálkamat várhatóan emelkedni fog, azért mert az olasz államadósság finanszírozására hatalmas összegre lesz szükség. A befektetőknek idővel egyre kockázatosabbá fog válni a finanszírozás, ezért azt várják el, hogy az olasz költségvetés magasabb kamatot fizessen az állami kötvényekre.

\section{Adat és módszertan}

Összefoglalva: egy országnak a várható államadósság rátája alapvetően az előző mondatokban bemutatott reálkamat és gazdasági növekedés viszonyától, illetve az államháztartás elsődleges egyenlegétől függ (Balatoni-Tóth, 2011). Releváns 
tényező még az államadósság alakulásában a devizában fennálló adósságrész esetleges átárazódása. Amennyiben a nemzeti deviza leértékelődik, akkor a devalválódás értéke növeli, amennyiben felértékelődik, akkor a pozitív értékkülönbözet csökkenti az államadósságot. Azért, mert az olasz államadóság döntően euróban denominált, így ezzel a tényezővel a tanulmányban nem kell számolni.

A tanulmány készítésének időpontjában a gazdasági visszaesés értékének meghatározása az egyik releváns tényező. Ennek definiálására a koronavírus járvány európai megjelenését követően az Európai Parlament honlapján nyilvánosságra hozott országonkénti adatokat fogom felhasználni. Ezek az adatok az adott Uniós tagország jegybankjainak jelentéseiből származnak, de nem teljes körüek (EP, 2020). Másik két alapvető adatforrást a világméretü járványt követően megjelent (World Bank, 2020), valamint a Nemzetközi Valutaalap (IMF, 2020) elörejelzései képezték.

Költségvetés elsődleges egyenlegének becsléséhez az Uniós tagországok államháztartási elsődleges egyenlegének prognosztizálása is sok bizonytalanságot hordoz. A költségvetési egyenlegek jövőbeli értékeinek adatforrását is az EP, WB és IMF adatbázisok képezték.

Fontos változás az Unió korábbi szabályozásához képest az, hogy a koronavírusjárvány okozta gazdasági helyzetre tekintettel az Európai Unió felfüggeszti az államháztartási hiányra vonatkozó szigorú szabályokat. Erre a lazításra azért van szükség, hogy lehetővé váljon a tagállami kormányok számára a gazdaság rugalmasabb finanszírozása. A döntés a gyakorlatban azt jelenti, hogy az Unió engedi a tagállamok költekezését a járvány elleni védekezés, valamint a koronavírushelyzet gazdaságra gyakorolt hatásának minimalizálása érdekében. Mindeközben az Unió eltekint a költségvetési hiányra vonatkozó szabályoktól (Portfólió, 2020). Ezek egyik alaptétele a 3 százalék alatti GDP-arányos deficitkorlát, amely így túlléphetö lesz az olaszok által is.

A reálkamat előrejelzése is sok bizonytalansági tényezőt tartalmaz. A bizonytalanság ellenére a koronavírus járvány elleni védekezés során mind fiskális, mind monetáris élénkítés kezdődött el a fejlett nemzetgazdaságokban, így Olaszországban is. Ez elméletileg a jelenlegi kamatszintek megmaradását erősíti. Álláspontom szerint azonban a megemelkedő államadósságok finanszírozása hatalmas új források kényszerü bevonását teszi szükségessé. Ebböl következően megítélésem szerint a jelenlegi negatív reálkamatok 2021 végére megszünnek az Unió tagországainak többségében, 2022-ben pedig már várhatóan az Unió összes nemzetgazdaságában pozitívak lesznek. Ezt a tendenciát építettem be az Olaszországgal kapcsolatos modellszámításba is.

A következő makroökonómiai modell alkalmas elöre jelezni egy nemzetgazdaság várható államadósságát:

ahol:

$$
b_{t}=\left[\left(1+r_{t-1}\right) /\left(1+g_{t^{-1}}\right)\right] b_{t-1-1}-p b_{t}
$$


b és pb a GDP-arányos államadósságot, illetve a költségvetés elsődleges egyenlegét jelöli, $\mathrm{r}$ a reálkamatot, $\mathrm{g}$ pedig a gazdasági növekedést. A t alsó index a tárgyévet jelöli.

A koronavírus járvány hatására Olaszország várható bruttó államadóssága növekedni fog. Az államadósság mértékének az alakulásában azonban nem mindegy, hogy a járvány milyen forgatókönyv szerint fog lezajlani. Összesen négy különböző verzióban vizsgálom meg azt, hogy mennyi lesz az olasz államadósság-ráta a járvány végére. A járvány négy lehetséges forgatókönyve a következő alakzatokat írhatja le: $\mathrm{V}, \mathrm{W}, \mathrm{U} 1$ és U2 alak /ezekről a lehetséges forgatókönyvekről lásd részletesebben (FC, 2020)/. A 2022 évre előre jelzett olasz gazdasági adatok arra vonatkoznak, hogy ebben az évben véget ér a koronavírus járvány és még ebben az évben az ország gazdasága visszatér a járványt megelőző évben prognosztizált gazdasági növekedéshez. Olaszország esetében ez a válságtól függetlenül is negatívra volt korábban betervezve.

A négy járvány-forgatókönyv szerint várható makrogazdasági változók értékeit mutatja az 1. táblázat.

\section{1. táblázat: A makroökonómiai modell input értékei az olasz GDP} százalékában (2020-2022)

\begin{tabular}{|c|c|c|c|c|c|c|c|c|c|c|c|c|c|c|}
\hline \multicolumn{5}{|c|}{ GDP alakulása (g) } & \multicolumn{5}{|c|}{ Reálkamat (r) } & \multicolumn{5}{|c|}{ Költségvetési hiány (pb) } \\
\hline \multicolumn{3}{|c|}{2020} & 2021 & 2022 & 2020 & & & 2021 & 2022 & 2020 & & & 2021 & 2022 \\
\hline V & $\begin{array}{l}\text { W } \\
\text { p. }\end{array}$ & $\begin{array}{l}\text { U1 } \\
\text { p. }\end{array}$ & $\begin{array}{l}\text { U2 } \\
\text { p. }\end{array}$ & $\begin{array}{l}\text { Krí- } \\
\text { zis } \\
\text { után }\end{array}$ & $\begin{array}{l}\text { V } \\
\text { p. }\end{array}$ & $\begin{array}{l}\text { W } \\
\text { p. }\end{array}$ & $\begin{array}{l}\text { U1 } \\
\text { p. }\end{array}$ & $\begin{array}{l}\text { U2 } \\
\text { p. }\end{array}$ & $\begin{array}{l}\text { Krí- } \\
\text { zis } \\
\text { után }\end{array}$ & $\begin{array}{l}\text { V } \\
\text { p. }\end{array}$ & $\begin{array}{l}\text { W } \\
\text { p. }\end{array}$ & $\begin{array}{l}\text { U1 } \\
\text { p. }\end{array}$ & $\begin{array}{l}\text { U2 } \\
\text { p. }\end{array}$ & $\begin{array}{l}\text { Krí- } \\
\text { zis } \\
\text { után }\end{array}$ \\
\hline$-9,1$ & $-11,3$ & $-8,2$ & $-3,1$ & 0,8 & 0,0 & 0,0 & 0,0 & 1,0 & 2,0 & $-8,3$ & $-10,3$ & $-6,6$ & $-3,7$ & $-1,3$ \\
\hline
\end{tabular}

(p.= járványpálya. A számításokhoz felhasznált bázis év 2019, adatok: államadósság: 134,8, gazdasági növekedés:0,1 a GDP arányában, reálkamat: 0 százalék)

Forrás: EP (2020),WB (2020), IMF (2020)

\section{Eredmények}

Bármilyen forgatókönyv alapján fog lezajlani a járvány, Olaszország államadóssága robosztus növekedést fog mutatni. Az input adatok felhasználásával Olaszország közeljövőben várható államadósságának GDP-hez mért arányára az alábbi 2. táblázatban és 2. ábrán látható végeredmények prognosztizálhatók:

\section{2. táblázat: Várható államadósság növekedések Olaszországban különböző} járvány forgatókönyvek esetében, a GDP százalékában (2019-2022)

\begin{tabular}{|c|c|c|c|c|c|c|}
\hline 2019 & \multicolumn{3}{|c|}{2020} & 2021 & 2022 & Változás a \\
\hline Bázis év & V-pálya & W-pálya & U/1 pálya & $\mathrm{U} / 2$ pálya & Krízis után & (2021-2019) \\
\hline 134,8 & 156,6 & 162,3 & 153,4 & 163,6 & 166,8 & $+28,8$ \\
\hline
\end{tabular}

Forrás: saját számítás 


\section{2. ábra: Olaszország várható államadósság rátájának növekedése eltérö járvány lefutások esetében a GDP százalékában}

35

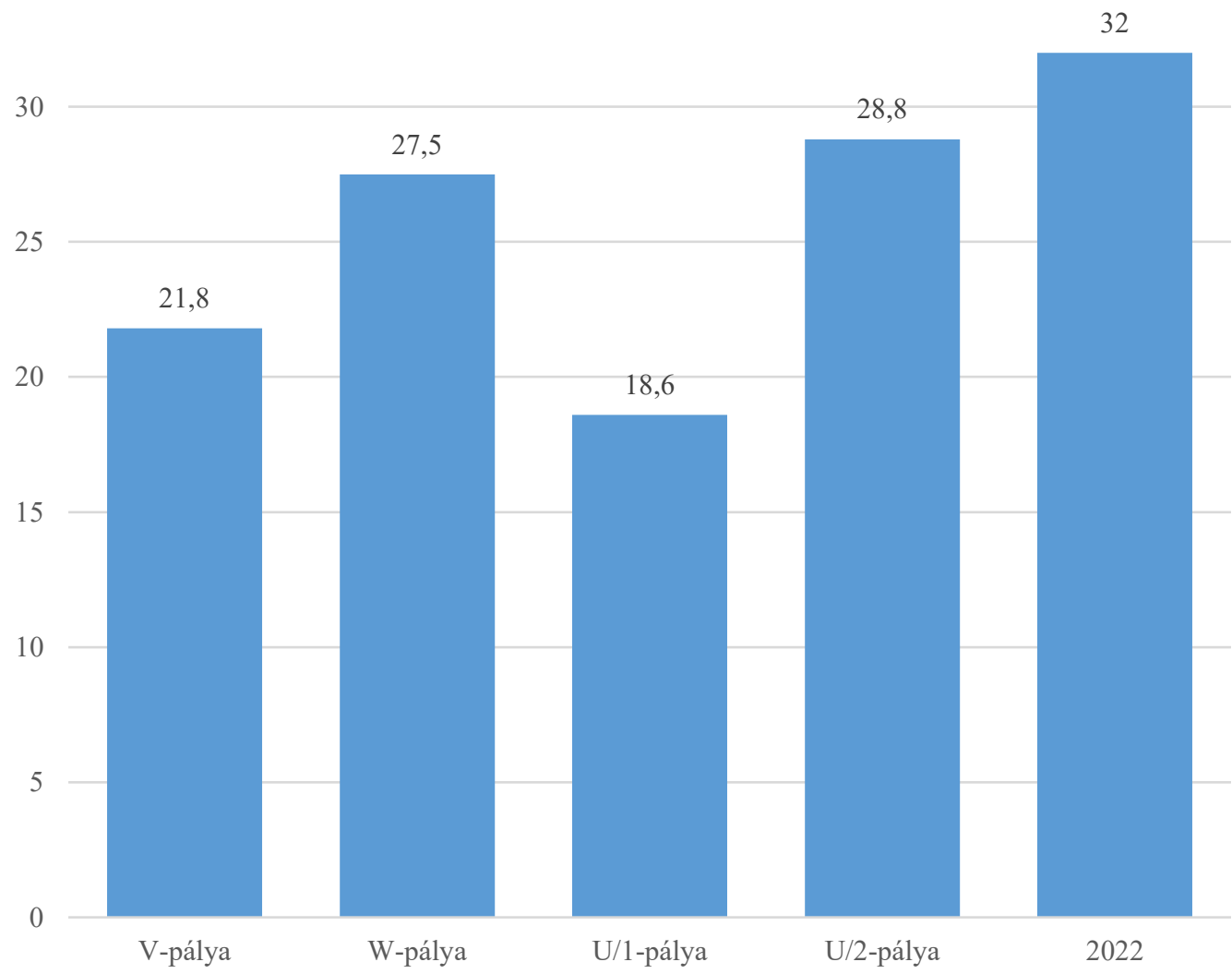

Forrás: saját szerkesztés

Az olasz állam bruttó államadósság-rátája a koronavírus járvány miatt a fenti adatok alapján biztosan hatalmas mértékben fog növekedni. Az adósság növekedése a járvány bármilyen forgatókönyve szerint is legkevesebb 21,8 százalék (V-pálya), legrosszabb esetben 28,8 százalék (U/1+U/2 pálya). Olaszország 2022-re várható államadóssága is növekedést mutat (+32 százalék a 2019. év rátájához mérve). Ez ellentétben áll az Európai Unió tagországainak várható államadósság adataival, ugyanis az olaszokon kívül minden más nemzetgazdaságnak az államadóssága ekkorra már csökkeni fog az elörejelzések szerint.

Ha figyelembe vesszük az olaszok 2019 évi bruttó államadósságának 2300 milliárd eurós összegét, kiszámítható az, hogy az adósság növekedés abszolút összege 501,4 és 662,4 milliárd euró között lesz. Önmagában az olasz államadósság finanszírozása az egész Európai Unió adósság növekedésének finanszírozására tervezett 1350 milliárd eurós keret az Euractiv (2020) szerint több, mint negyven százalékát igénybe fogja venni. 


\section{Következtetések}

Olaszország gazdaság helyzetét csak több mutatószám együttes elemzésével lehetséges megítélni. Ezen mutatószámok közül az egyik legfontosabb indikátor az államadósság, mivel alakulásában számos fontos gazdasági folyamat - gazdasági növekedés, kamatszint, költségvetési hiány - egyszerre tükröződik. Ezeknek az indikátoroknak az előrejelzését végezte el a tanulmány, a számított eredményekből az alábbi következtetéseket lehet levonni.

Az olasz államadósság közép- és hossztávú finanszírozásának vannak pozitív és negatív makroökonómiai faktorai. Pozitív elem az, hogy az államadósságot finanszírozó források reálkamatának /a nominális kamatláb és a várható infláció különbségének mértéke/ évtizedek óta nem tapasztalt alacsony szinten van. Napjainkban ennek mértéke a nulla közelében van. Ez azt jelenti, hogy az olasz állami költségvetés olcsón jut jelenleg finanszírozási forrásokhoz. A reálkamat rendelkezik azzal a képességgel, hogy ha annak mértéke annyira alacsony, hogy gazdasági növekedés üteme meghaladja azt, akkor az államháztartási eladósodás /az államadósság/ beavatkozás nélkül is stabilizálódik, bármekkora legyen is az induló adósságállomány.

A napjainkban tapasztalt alacsony reálkamat pozitívan képes hozzájárulni az olasz államadósság növekedésének csillapításához. Augusztus hónapban egy százalék alá süllyedt az olasz 10 éves kötvényhozam, amely egyben gyakorlatilag történelmi mélypontnak is megfelel. A modellszámítás eredményei azonban azt mutatják, hogy közép- és hosszú távon növekedni fog finanszírozási források iránt az olasz költségvetés kereslete, ami a reálkamatok növekedését fogja eredményezni. Ezt a pénzpiaci várakozást építettem be a számításokba és ennek negatív eredményei megmutatkoznak a 2021-2022 évek várható államadósság növekedésében.

A COVID-19 koronavírus okozta járvány, illetve a megelözésére hozott intézkedések következtében Olaszországban a gazdasági tevékenység drasztikusan visszaesett. Ennek következtében az állami bevételek számottevően mérséklődnek, miközben a járvány negatív hatásainak enyhítésére a jelentős pótlólagos költségvetési kiadásokat kell teljesíteni /vállalatok és háztartások támogatása, munkanélküli segély stb./. Ezek a várakozások megjelennek az elvégzett számításokban. A modellszámításban a költségvetési deficit a dinamikus tag azért, mert a hiány közvetlenül növeli az államadósságot. A legrosszabb járvány scenárióban a költségvetési hiány várható mértéke megközelíti a 15 százalékot az éves GDP-hez viszonyítva. Olaszország esetében az is hozzá fog járulni az államadósság növekedéséhez, hogy az előrejelzések szerint 2022-ben is deficites lesz a költségvetés, annak ellenére is, hogy ekkor már nem várható járvány.

Végül a gazdaság teljesítményének és az ebből következő GDP várható alakulásáról lesz szó a COVID-19 következményeként. Az olasz gazdaság teljesítménye az első negyedévben 5,4 százalékkal csökkent az előző negyedévhez képest, majd a második negyedévben további 12,4 százalékkal zuhant a GDP. Utóbbi egyébként valamelyest kedvezőbb volt a várakozásoknál. Napjainkban már biztos, hogy Olaszország sem reménykedhet a V-alakú kilábalásban, mivel elkezdődött a járvány második szakasza, sőt annak már harmadik szakasza várható. Ez alapján 
megalapozottnak tủnnek a modellszámításban alkalmazott negatív GDP értékek. A gazdasági visszaesés kevésbé dinamikus tag az alkalmazott modellben, mint a költségvetési hiány. Ez azzal magyarázható, hogy a GDP alakulása csak közvetten hat az államadósságra. A GDP növekedésekor növekszik a reálgazdaság kibocsátása, ennek következtében emelkednek az államnak befizetett adók és járulékok, ezért van pénzügyi forrása az államadósság csökkentésének. Recesszióban éppen fordítva, csökkennek az állam bevételei, és ha hiány alakul ki a költségvetésben, akkor növekszik az államadósság. Olaszország azok közé az Uniós tagországok csoportjába tartozik, amelyekben a legnagyobb mértékben csökkent a reálgazdaság kibocsátása, tehát a GDP.

Olaszország államadósságát szimuláló kutatás alapján megalapozottnak tünik az, hogy középtávon drasztikusan növekedni fog annak GDP-hez mért aránya. Az olasz gazdaság Európa harmadik legnagyobb gazdasága, nagy összegü GDP-vel, és ebből következően abszolút összegben gigantikus összegü államadóssággal. Azonban az eurózónából nem lehetséges a kilépés (Nizzai Szerződés, 2001), amely lehetőség ilyen esetben teoretikusan felmerülhet a finanszírozással összefüggésben.

Olaszország jelenleg még tudja finanszírozni államadósságát a nemzetközi pénzpiacokon. Középtávon azonban már bizonytalan az, hogy az olaszok képesek lesznek elegendő forráshoz jutni. Elméletileg tehát nem zárható ki egy rendezett államcsőd végrehajtása. A rendezett államcsőd során a hitelezőket felszólítanák az olaszok arra, hogy az olasz államadósságot finanszírozó államkötvények értékének egy részéröl ök önként mondjanak le. A COVID-19 járvány következményeként egy ilyen nem szokványos döntés talán nem is okozna nagy meglepetést a befektetők körében. A rendezett államcsőd nem ismeretlen az Európai Unióban, mivel Görögország esetében ez megtörtént már 2012-ben (Török, 2018).

\section{Irodalomjegyzék}

Arena, M. (2010): The Corporate Choice between Public Debt. Bank Loans, Traditional Private Debt Placements, and 144A Debt Issues. Review of Quantitative Finance and Accounting 36(3). https://doi.org/10.1007/s11156-010-0182-3

Arestis, P. (2014): Coordination of Fiscal with Monetary and Financial Stability Policies Can Better Cure Unemployment. University of Cambridge, UK. 1-17. https://doi.org/10.4337/roke.2015.02.07

Balatoni A., Tóth G. Cs. (2011): Fenntartható makrogazdaság és államadósság-kezelés. Nemzeti Fenntartható Fejlődési Tanács, Budapest,

Benczes I., Kutasi G. (2016): Hiány, államadósság és fenntarthatóság. Költségvetési pénzügyek. Akadémiai Kiadó, Budapest. https://doi.org/10.1556/9789630598422

Blanchard, O., Dell'Ariccia, G., Mauro, P. (2010): Rethinking Macroeconomic Policy. IMF staff Position Note, sPN/10/03. https://doi.org/10.5089/9781455224982.004.a001

Czékus B. (2012): Olaszország és az európai gazdasági kormányzás reformja: közösségi kihívások és nemzeti érdekek. Külügyi Szemle, 2012. 3. szám, 1-25.

European Parlament (2020): The economy and coronavirus: Weekly Picks. $<$ https://www.europarl.europa.eu/RegData/etudes/BRIE/2020/645717/IPOL_BRI(2020)64571 7_EN.pf> (2020.10.02.)

Eurostat (2020): General government gross debt-annual data. $<$ https://ec.europa.eu/eurostat/databrowser/view/teina225/default/table? lang=en $>(2020.10 .12$.) 
Euractiv (2020): EU Commission will propose 'borrowing' to finance recovery plan: Dombrovskis. $<$ https://www.euractiv.com/section/economy-jobs/news/eu-commission-will-proposeborrowing-to-finance-recovery-plan-dombrovskis/> (2020.10.22.)

Fastcompany (2020): U-shaped or V-shaped recovery? Here's your guide to the geometry of recessions. <https://www.fastcompany.com/90494041/u-shaped-or-v-shaped-recovery-heresyour-guide-to-the-geometry-of-recessions $>(2020.10 .24$.)

Grimaldi, F., (2019): The relationship between financial crisis and earnings management: Some evidence from the Italian context. January 2019 Corporate Ownership and Control 17 (1): 325335. https://doi.org/10.22495/cocv17i1siart13

Herndon, T., Ash, M., Pollin, R. (2014): Does high public debt consistently stifle economic growth? A critique of Reinhart and Rogoff. Cambridge Journal of Economics, 38 (2): 257-279. https://doi.org/10.1093/cje/bet075

International Monetary Found (2020): World Economic Outlook, April 2020 Chapter 1. $<$ https://www.imf.org/en/Publications/WEO/Issues/2020/04/14/weo-april-2020> (2020.11.01.)

Index (2020): A koronavírus megtalálta az eurózóna leggyengébb láncszemét. $<$ https://index.hu/gazdasag/2020/03/07/olaszorszag_koronavirus_gazdasag_novekedes_valsag_ penzugyi_szektor_rossz_hitelek_bankok/> (2020.10.03.)

Nizzai Szerződés (2001): Treaty of Nice amending the Treaty on European Union, the Treaties establishing the European Communities and certain related acts. $<$ https://eurlex.europa.eu/legal-content/EN/TXT/HTML/?uri=CELEX:12001C/TXT\&from=HU> (2020.11.05)

Portfólió (2020): Ilyet még soha sem csinált Brüsszel: felfüggeszti a deficitre vonatkozó szabályokat. $<$ https://www.portfolio.hu/gazdasag/20200320/ilyet-meg-soha-sem-csinalt-brusszelfelfuggeszti-a-deficitre-vonatkozo-szabalyokat-421019\#> (2020.11.02)

Reinhart, C. M., Rogoff, K. S. (2010): Growth in a time of debt. American Economic Review: Papers \& Proceedings, 100., 573-578. https://doi.org/10.1257/aer.100.2.573,

Reuters (2019): Italian banks face 2019 funding crunch without ECB help. $<$ https://www.reuters.com/article/us-italy-banks-funding/italian-banks-face-2019 fundingcrunch-without-ecb-help-idUSKCN1P928H> (2020.11.29)

Research and Markets (2020): Impact of COVID-19 on the Italian Economy. $<$ https://www.researchandmarkets.com/reports/5013540/impact-of-covid-19-on-the-italianeconomy> (2020.10.01.)

Tomomi M., Kazuki, O. (2017): The Sustainability of Japan's Government Debt: A Review. Theoretical Economics Letters, 2017, 7, 1632-1645. https://doi.org/10.4236/tel.2017.76110,

Török L. (2012): A magyar államadósság lehetőségei és lehetetlenségei. Competitio, 11 (2): 26-42. https://doi.org/10.21845/comp/2012/2/2

Török L. (2018): Görögország államadósság-válsága kezelésének jövőbeli jogi és közgazdasági akadályai - a privatizáció mennyiben lehet megoldás?. Külgazdaság, 62 (1-2): 4-26. https://doi.org/10.21791/IJEMS.2019.4.13

Török L. (2020): A koronavírus miatti államadósság-növekedés az Európai Unió országaiban /A válságból való kilábalás utáni államadósság-ráták eltérő recessziós scenáriók mentén/. Pénzügyi Szemle 2020/3, 350-363. https://doi.org/10.35551/PSZ 202032

World Bank (2020): Fighting COVID-19, Office of the Chief Economist. $<$ https://openknowledge.worldbank.org/bitstream/handle/10986/33476/9781464815645.pdf?se quence $=5 \&$ is Allowed $=\mathrm{y}>(2020.12 .01$. $)$ 